\title{
Investigation on Fly Ash-Lime-Gypsum Mix Mixed with Stone Dust
}

\author{
Nitin $^{1}$, Tapesh Behl², Rachit ${ }^{3}$, Kapil Dev Patyal ${ }^{4}$ \\ 1, 2,3,4 B.Tech Civil Engineering Student, Jawaharlal Nehru Government Engineering College, Sundernagar, Mandi (H.P), India
}

\begin{abstract}
Stone Quarry dust is a kind of solid waste material that is generated from stone crushing site which is abundantly available. It is estimated that there are over 12000 stone crusher units in India (Central Pollution Control Board Parivesh Bhawan East Arjun Nagar, Shahdara Delhi). Disposal of such wastes poses lots of environmental problems such as air pollution, health and environmental hazards. The best way to eliminate these problems is to make use of such waste. The research aims to utilize the bye-products of stone quarries i.e. stone dust and thermal power plants i.e. fly-ash by investigating their basic properties when combined together which can help to enhance the strength of composite materials. Keeping this in view an experimental study was conducted on locally available stone dust by mixing it with fly ash-lime-gypsum mix. The compressive strength of composite of fly ash-lime-gypsum-stone dust was found to increase after Burlap method of curing.
\end{abstract}

Keywords: OMC, MDD, UCS, Stone Dust

\section{Introduction}

In the present scenario, with the increase in the facilities and modernization the by-products of different activities are required to be used in such a way that they can be used to the best of their potential. The construction industry can start being aware of and take advantage of the benefits of using waste and recycled materials. Stone dust and fly ash are examples of such bye-products produced in large quantities from stone quarries and thermal power plants. The disposal of such waste materials is of great concern. The best method to dispose of the products is use them to make composite materials along with other basic construction materials which can be applied in various ways in construction of different types of infrastructure. The essential properties of such composite materials need to be investigated first so that their applications can be defined later. Experimental studies have to be carried out by combining fly ash, lime and gypsum togther, which are necessary elements of construction materials due to their good properties, and adding quarry dust to the composite to study its effect on the overall properties of the mix. Kumar Siva and Prakash (2011) experimentally showed that the addition of quarry dust for a fine to coarse aggregate ratio of 0.6 was found to enhance the compressive properties as well as elastic modulus. Sivapullaiah and Moghal (2011) have reported that strength of fly ash, lime mix increases only up to the addition of optimum lime content as higher content beyond the optimum may have deleterious effect. Further experimental investigations on fly ash-lime-gypsum-stone dust have been studied in this research to use the waste product along with other materials.

\section{Literature Review}

Very little information has been published on the unconfined compressive strength of various materials mixed with quarry dust. However, various studies have been conducted regarding use of quarry dust to improve properties of some materials.
Balamurugan and Perumal (2013) has suggested that maximum compressive strength, tensile strength and flexural strength can be obtained only at 50\% replacement of sand with quarry dust.

Sumathi A and K. Saravana Raja Mohan (2015) reported changes in compressive strength of fly ash bricks by addition of fly ash quarry dust and lime.

Fraay et al. (1990) reported that the fly ash produced by some of the thermal power plants in India and abroad contains low lime content. Lime is added to stabilize such fly ashes.

Sivapullaiah and Moghal (2011) have reported that strength of fly ash, lime mix increases only up to the addition of optimum lime content as higher content beyond the optimum may have deleterious effect.

Guleria S.P and Dutta R.K (2011) reported the effect of inclusion of randomly distributed tire chips on the compressive axial load, tensile load, compressive axial strain, diametric strain, post peak behavior in compression, and tension and toughness index of the reference mix containing fly ash $+8 \%$ lime $+0.9 \%$ gypsum mix. The results revealed that the compressive axial and diametric strain of reference mix mixed with $5 \%$ dry tire chip increased with treatment.

Kumar Arun U and Biradar Kiran B. (2014) reported that the addition of the Quarry dust to the soil reduces the clay content and thus with the increase in the percentage of coarser particles, reduces the Liquid limit by $26.86 \%$ and plasticity index by $28.48 \%$ of unmodified soil.

Venkateswarlu $H$ et al.,(2015) reported that when expansive soil is mixed with different percentages $(0 \%, 5 \%$, $10 \%$ and $15 \%$ ) of Quarry dust and the results were found that up to the addition of $10 \%$ of stone dust there is an increase in strength parameters beyond it is not effective. 


\section{International Journal of Science and Research (IJSR) \\ ISSN (Online): 2319-7064 \\ Index Copernicus Value (2015): 78.96 | Impact Factor (2015): 6.391}

Dutta R.K and Kumar Vaibhav(2015) reported that addition of $1 \%$ gypsum along with $10 \%$ lime to the fly ash enhanced the unconfined compressive strength by 36.7 times. It was studied that the improvement in unconfined compressive strength is due to fly ash lime reaction as well as the catalyzing effect of gypsum.

\section{Materials Used}

- Fly ash: The fly ash used in the study was procured from Ropar Thermal Power Plant, Punjab, India.

- Lime: Commercially available lime in the local market was used in the study.

- Gypsum: Commercially available gypsum in the local market was used in the study.

- Quarry Dust:-Stone dust was obtained from a local stone crushing site and was used in the study.

\section{Experimental Programme}

For carrying out the investigations, fly ash and lime were combined gypsum kept as $0.8 \%$ of fly ash and varying the stone dust content in different samples for determining optimum moisture content, maximum dry density and unconfined compressive strength.

In order to determine maximum dry density (MDD) and optimum moisture content (OMC) of Fly ash-stone dustgypsum mix by varying the lime content as $6 \%$ $, 8 \%, 10 \%, 12 \%, 14 \%$ of fly ash and keeping the gypsum content as $0.8 \%$ of fly ash, standard proctor tests were conducted as per IS:2720 (Part VII)-1980.

Unconfined compression strength (UCS) tests were conducted in accordance with IS 4332, Part 5 (BIS 1970). The Unconfined compressive strength was carried out on specimens with varying proportions of stone dust as $0 \%$, $10 \%, 20 \%, 30$ and $40 \%$ for different curing periods and different curing methods.

\section{Results and Discussion}

\subsection{Standard proctor test}

The optimum dry density obtained from the OMC curve of $8 \%$ lime is $1.35 \mathrm{~g} / \mathrm{cm}^{3}$ and the optimum moisture content is $29 \%$.The following fig 5.1(a) represents the OMC curves obtained from standard proctor test:-

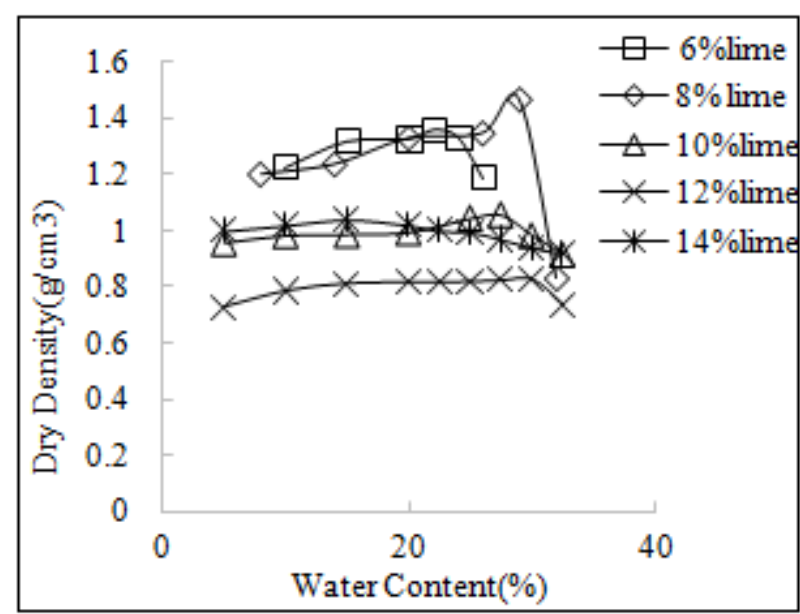

Figure 5.1: (a) Optimum moisture content curves for different $\%$ of lime

\subsection{Unconfined Compressive Strength}

Unconfined compressive strength (UCS) tests were conducted in accordance with IS 4332: Part 5: (1970) (Re affirmed on 03/2001). The strain rate was kept 0.048 $\mathrm{mm} / \mathrm{min}$ in all the experiments. The proving rings of capacity $2 \mathrm{KN}$ to $5 \mathrm{KN}$ were used for testing specimens cured for 14, 28 with two different methods M1, M2. The UCS increased with curing period and curing method and the increase was significant up to a curing period of 28 days. The maximum increase in UCS of the reference mix with quarry dust was observed when the specimen was cured by method M2. The Unconfined compressive strength of the specimen with $0 \%, 10 \%, 20 \%, 30$ and $40 \%$ of quarry dust get the different change with different curing periods and different curing methods are explained in Table 5.2(a)

\begin{tabular}{|c|c|c|c|c|c|}
\hline \multirow{2}{*}{$\begin{array}{c}\text { Stone dust } \\
\text { proportion }\end{array}$} & $\begin{array}{c}\text { Curing } \\
\text { period }\end{array}$ & $\begin{array}{c}\text { Axial } \\
\text { Strain (\%) }\end{array}$ & $\begin{array}{c}\text { Axial stress } \\
(\mathrm{KPa})\end{array}$ & $\begin{array}{c}\text { Axial } \\
\text { Strain (\%) }\end{array}$ & $\begin{array}{c}\text { Axial stress } \\
(\mathrm{KPa})\end{array}$ \\
\hline \multirow{2}{*}{0} & 14 & 21.052 & 355.018 & 21.052 & 150.3608 \\
& 28 & 20.543 & 298.975 & 23.234 & 205.457 \\
\hline \multirow{2}{*}{10} & 14 & 21.052 & 1837.74 & 18.421 & 172.636 \\
& 28 & 21.052 & 375.901 & 31.574 & 350.147 \\
\hline \multirow{2}{*}{20} & 14 & 21.052 & 2113.40 & 18.421 & 210.346 \\
& 28 & 18.421 & 1596.88 & 21.053 & 501.36 \\
\hline \multirow{2}{*}{30} & 14 & 21.052 & 1735.56 & 21.052 & 605.619 \\
& 28 & 21.052 & 1545.37 & 23.684 & 686.780 \\
\hline \multirow{2}{*}{40} & 14 & 21.052 & 1512.12 & 23.684 & 888.242 \\
& 28 & 21.052 & 1332.14 & 26.315 & 1200.839 \\
\hline
\end{tabular}

\subsubsection{Variation of axial stress with curing period}

The axial stress of specimen R2014M1 is $2113.404 \mathrm{KPa}$ which decreases to the 1596.887 with the increase in the curing period to the 28 days. In the curing method M2 the axial stress increases with the increase in the curing period. The stress value for the specimen R2014M2 is $210.346 \mathrm{KPa}$ and after 28 days is $501.36 \mathrm{KPa}$. ). The figure shows that the axial stress decreases with the increase in the curing period for the method M1. 
International Journal of Science and Research (IJSR)

ISSN (Online): 2319-7064

Index Copernicus Value (2015): 78.96 | Impact Factor (2015): 6.391

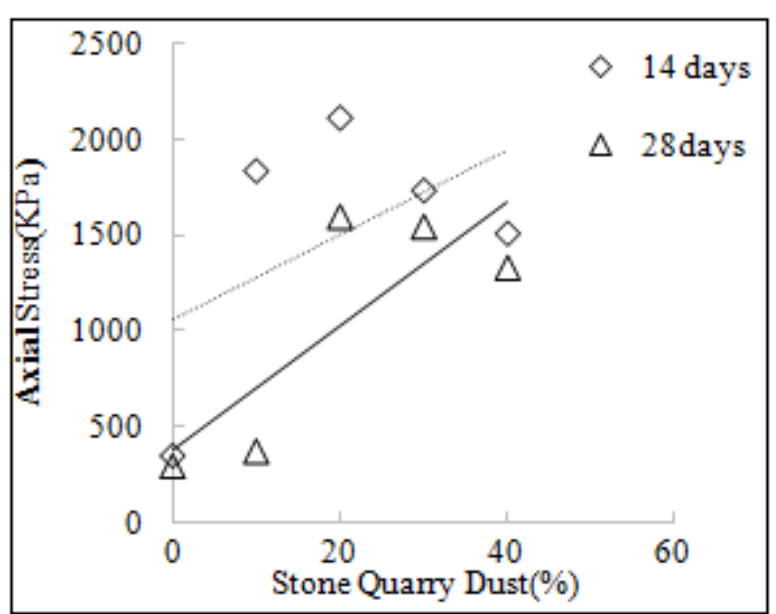

(a)

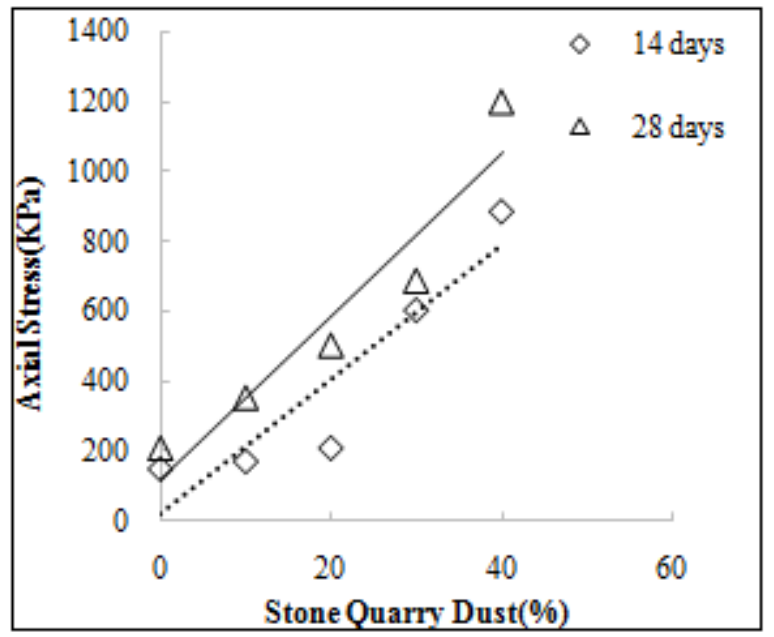

(b)

Figure 5.2 (a) and (b) shows the variation of axial stress with different $\%$ of quarry dust by different curing period M1, M2 respectively

\subsubsection{Variation of axial stress with change in curing method}

The axial stress of the specimen R14M1 for M1 method of curing was $355.018 \mathrm{KPa}$, which decreased to $150.360 \mathrm{KPa}$ with the increase in curing method to M2. Similarly for the various proportions of quarry dust the axial stress value decreases with change in curing method. Figure reveals that axial stress of the reference mix and reference mix mixed with quarry dust $(0 \%, 10 \%$, and $20 \%, 30$ and $40 \%)$ decreases with the change in the curing methods. The results of the unconfined compressive strength of the reference mix with varying content of quarry dust and cured for different methods are shown in the Fig 5.4

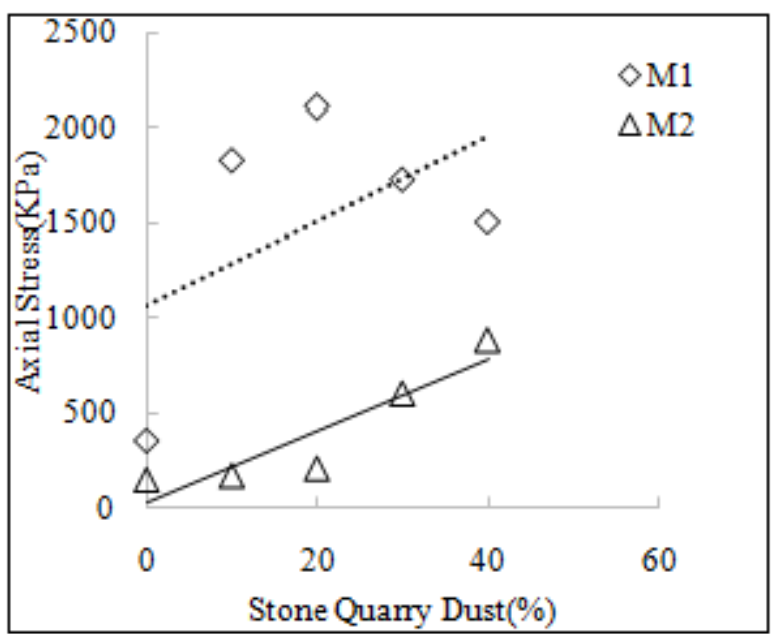

(a)

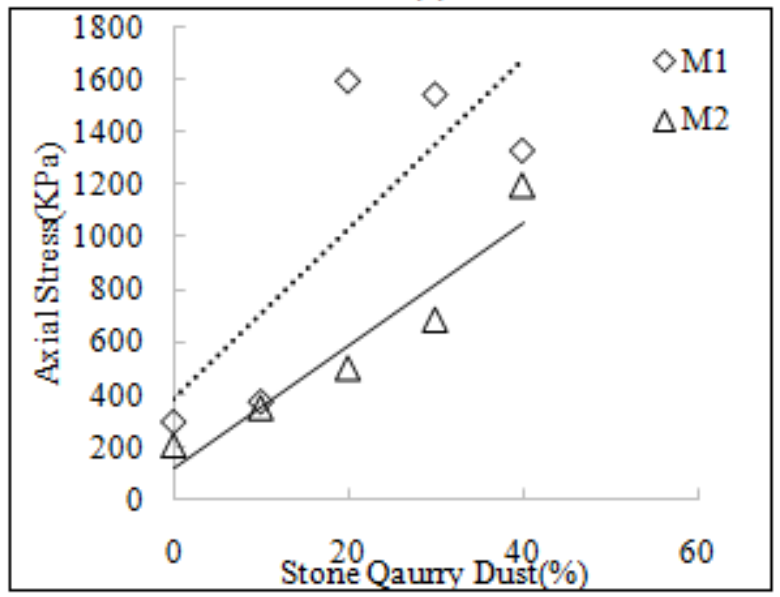

(b)

Figure 5.3 (a) and (b) shows variation of UCS of reference mix with quarry dust (\%) by M1, M2 methods of curing for curing period of 14 and 28 days respectively.

\subsubsection{Variation of axial stress with increase in the quarry dust}

The axial stress of the specimen R14M1 for M1 method of curing is $355.018 \mathrm{KPa}$, which increases to $2113.404 \mathrm{KPa}$ with the increase in \% of quarry dust to R2014M1 after that it decreases to $1512.127 \mathrm{KPa}$ with the increases in \% of quarry dust to R4014M1. The axial stress of the reference mix and reference mix mixed with quarry dust $(0 \%, 10 \%$, $20 \%, 30$ and $40 \%$ ) first increases than decreases with the increase in the $\%$ of quarry dust. The results of the unconfined compressive strength of the reference mix with varying content of quarry dust and cured for different methods are shown in the Fig 5.5 (a), (b), (c), (d) 
International Journal of Science and Research (IJSR)

ISSN (Online): 2319-7064

Index Copernicus Value (2015): 78.96 | Impact Factor (2015): 6.391

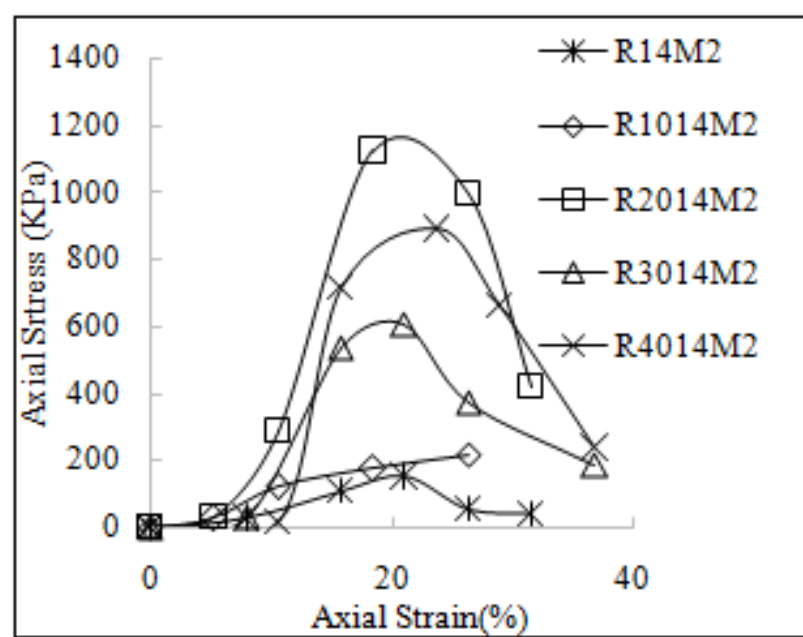

(a)

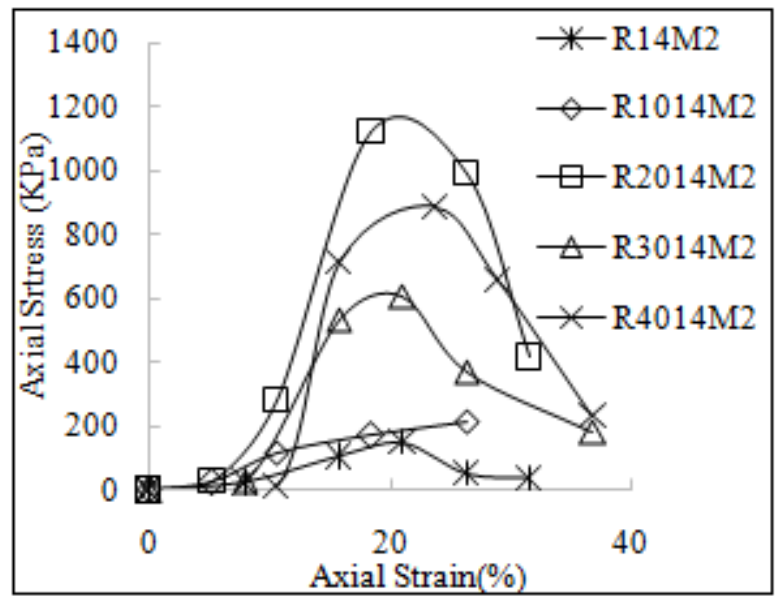

(b)

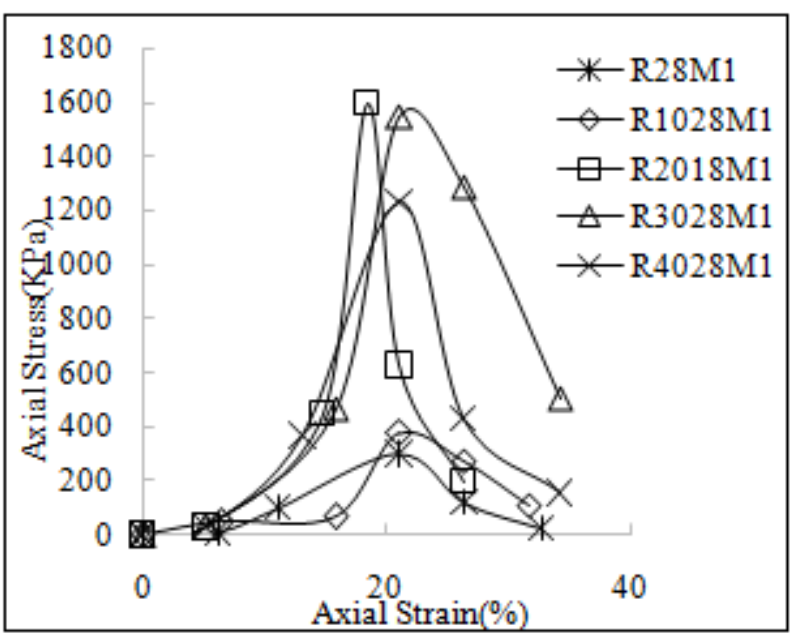

(c)

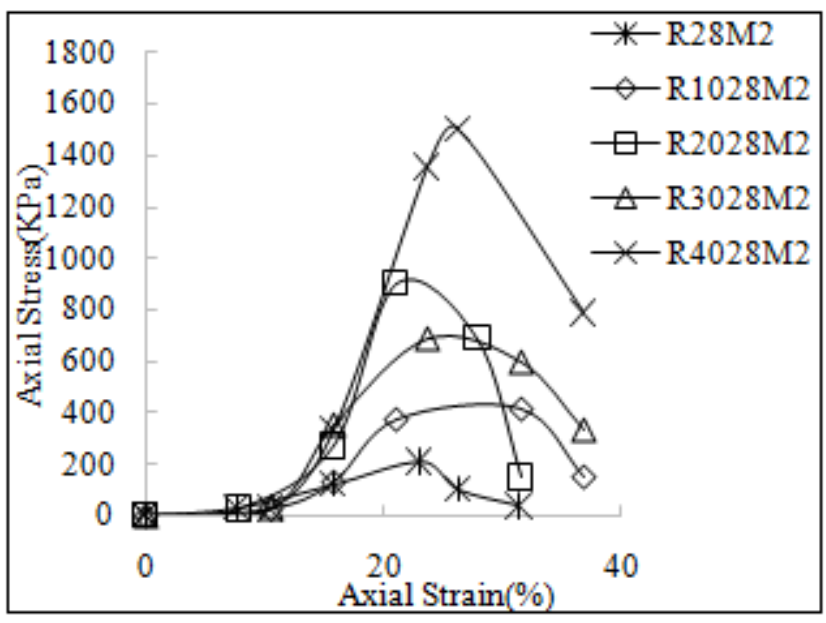

(d)

Figure 5.4 Variation of axial stress with respect to axial strain with variation of stone quarry dust and (a)M1 method and 14 days curing period;(b)M2 methods and 14 days curing period;(c)M1 method and 28 days curing period;(d)M2 method and 28 days curing period.

\section{Conclusion}

1) This value of lime along with fly ash and gypsum in proportion of $1 \%$ fly ash: $0.8 \%$ gypsum gives best results of dry density that can be obtained at a water content of $29 \%$. The maximum dry density obtained is $1.35 \mathrm{~g} / \mathrm{cm} 3$.

2) The results show that in dry method of curing the compressive strength decreases with the increase in the curing period from 14 to 28 days. While in burlap method of curing the compressive strength increases with the increase in the curing period.

3) It was observed that the for the dry method of curing the compressive strength increases upto $20 \%$ quarry dust addition and then decreases for $30 \%$ and $40 \%$ quarry dust addition with fly ash for 14 and 28 days of curing period. In burlap curing method the compressive strength of the specimen increases with the increase in the quarry dust upto $40 \%$ for the 14 and 28 days of curing period.

4) The results shows that for the dry curing method axial strain remains constant for the 14 days of curing and different proportions of quarry dust while it increases for the 28 days of curing upto $10 \%$ and then decreases .For burlap method of curing the axial strain first decreases upto $10 \%$ and then starts increasing for 14 days of curing period while it increases upto $10 \%$ and then decreases for the 28 days of curing period.

\section{References}

[1] Balamurugan, G. and Perumal, P. (2013). "Behavior of concrete on the use of quarry dust to replace sand - an experimental study." An International Journal (ESTIJ), 3(6), 776-781.

[2] Das, K Ananta et al. (2015). "Studies on Interaction of Fly ash with Lime in the presence of varying quantity of Sand. " International Research Journal of Engineering and Technology (IRJET), 2(9), 2451-2455.

[3] Goutham Bhramananda et al. (2016). "An Experimental Study of Fiber Reinforced geo Polymer Concrete using Fly ash GGBS and Polypropylene Fibers 


\section{International Journal of Science and Research (IJSR) \\ ISSN (Online): 2319-7064 \\ Index Copernicus Value (2015): 78.96 | Impact Factor (2015): 6.391}

with the partial replacement of Normal Sand by Quarry Dust." International Journal of Engineering Research and Technology, 5(5), 214-218.

[4] Guleria, S.P. and Dutta, R.K. (2013). "Study of Flexural Strength and Leachate Analysis of Fly Ash- LimeGypsum Composite Mixed with Treated Tire Chips." KSCE Journal of Civil Engineering, 17(4), 662-673.

[5] Jamale H, Anjali and Kawade R, Urmila. (2015). "Effect of Quarry Dust and Fly Ash on strength properties M40 grade concrete." International Journal of Engineering Research and General Science, 3(3), 391-397.

[6] Kumar, Arun U. and Biradar, Kiran B. (2014). "Soft Sub grade stabilization with Quarry Dust- An Industrial Waste." International Journal of Research in Engineering and Technology, 3(8), 409-412.

[7] Kumar Sai, A.V.S and B, Krishna Rao. (2014). "A study on the strength of concrete with Partial replacement of cement with quarry dust and Metakaolin." International Journal of Innovative Research in Science, Engineering and Technology, 3(3), 10467-10473.

[8] Mir Hamid Anzar. (2015). "Improved Concrete Properties Using Quarry Dust as Replacement for Natural Sand." International Journal of Engineering Research and Development, 11(3), 46-52.

[9] M,Vinay et al. (2015). "Experimental studies on strength characteristics of concrete using Fly ash aggregate and quarry dust." International Journal of Civil and Structural Engineering Research, 3(1), 355359.

[10]Rao Krishna, S. and Prakash Bhanu. (2015). "Composite mixture of stone dust and fly Ash as a sub grade in rural roads. " International Journal of Research in Engineering and Technology, 4(1), 95-99.

[11] Rai baboo et al. (2014). "Effect of Fly ash on Mortar Mixes with the Quarry Dust as a fine Aggregate." Hindwai Publishing Corporations, Advances in Material Science and Engineering, 2014, 1-7.

[12] Shakir, A.A. et al. (2014). "Effect of Quarry Dust and Billet Scale Additions on the Properties of Fly ash Bricks."IJST, Transactions of Civil Engineering, 38(1), 51-60.

[13] Sivakumar, A. and M, Prakash. (2011). "Characteristic studies on mechanical properties Of quarry dust addition in conventional concrete." Journal of Civil Engineering and Construction Technology, 2(10), 218235.

[14] Sukesh Chandana et al. (2013). "Partial replacement of Sand with Quarry dust in Concrete." International Journal of Innovative Technology and Exploring Engineering (IJITEE), 2(6), 254-258.

[15] Sumathi, A. and Mohan Raja Saravana, K. (2014-15). "Compressive Strength of Fly Ash Brick with Addition of Lime, Gypsum and Quarry Dust." International Journal of Chem Tech Research (IJCRGG), 7(1), 28-36.

[16] Sureshchandra, H.S.et al. (2014). "Experimental Investigation on the Effect of Replacement of Sand by Quarry Dust in Hollow Concrete Block for Different Mix Proportions."International Journal of Environmental Science and Development, 5(1), 15-19.

[17] Varshney Mayank et al. (2014). "Techno-Economic Feasibility Study of Stone Dust Fly Ash Cement Bricks over Ordinary Clay Bricks in Affordable Housing." International Journal of Scientific Engineering and Technology, 3(1), 63-69.

[18] Venkateshwarlu, H. et al. (2015). "Study on Behavior of Expansive Soil Treated With Quarry Dust.'International Journal of Engineering and Innovative Technology (IJEIT), 4(10), 193-196.

\section{Author Profile}

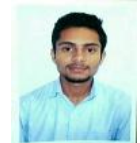

Nitin received his B. Tech degree in Civil Engineering from Jawaharlal Nehru Government Engineering College, Sundernagar, Mandi (H.P), India in the year 2017.

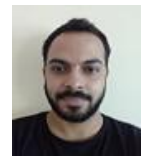

Tapesh Behl received his B. Tech degree in Civil Engineering from Jawaharlal Nehru Government Engineering College, Sundernagar, Mandi (H.P), India in the year 2017.

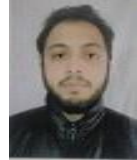

Rachit received his B.Tech degree in Civil Engineering from Jawaharlal Nehru Government Engineering College, Sundernagar, Mandi (H.P), India in the year 2017.

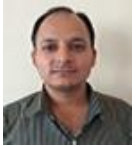

Kapil Dev Patyal received his M.E from National Institute of Technical Teacher And Research, Chandigarh (India) in the year 2013 and presently working as Assistant Professor, Dept. of Civil Engineering, Jawaharlal Nehru Government Engineering College, Sundernagar, Mandi (H.P), India. 